\title{
Topics in National Anthems
}

\author{
Radu Silaghi-Dumitrescu \\ rsilaghi@chem.ubbcluj.ro \\ Babes-Bolyai University, Institute for Interdisciplinary BioNanoSciences, ROMANIA
}

Abstract

Article

information

National anthems are occasionally quoted, mostly based on anecdotal evidence or arguments, to be correlated with societal features. The present study aims to identify the pervasive topics in national anthems, and then to establish whether connections may be established between these topics and some basic societal features. Upon examination of 200 anthems, such recurring themes were identified: ancestry/past, beauty, build/work, country name, courage, democracy, enemy, ethnicity, family, man, woman, fight, flag/colours, forever/never, future, geographical references, glory, independence/freedom, joy/happiness, home/mother/father-land, law/governance, leader, love, loyalty, peace, poverty/wealth, pride, religion, revolution, sacred, sacrifice, salvation, sorrow, treason, tyrant/chains, unity, win/victory. The number of topics, as well as their bias (e.g., towards identity, or towards fight, or towards general wellbeing), vary widely between anthems; groups of anthems may be identified based on these tendencies. Moreover, the number of topics, their bias, and/or the date of adoption can be proven to correlate to some extent to more general societal features such as date of adoption, age of country, gross domestic product (GDP) per capita, Gini coefficient, size of armed forces, inequality, inequality-adjusted human development index, and a number of parameters from the World Values Survey (WVS) database (related to religion, gender equality, attitude towards other nationalities/races, attitude towards work, attachment to democratic values etc). This set of data and the herein identified correlations may offer grounds for further, more detailed exploration of a variety of correlations between societal features and official narratives, starting with the national anthems as prime example.

Keywords: national anthem; identity; world values survey

DOI: 10.24071/joll.v20i2.2541

Available at https://e-journal.usd.ac.id/index.php/JOLL/index

This work is licensed under a Creative Commons Attribute-ShareAlike 4.0 International License

\section{Introduction}

When attempting to define cultural characteristics of a nation, crossnational/cultural comparative analyses of data may be deemed essential (Blaga, 1965; David, 2015; Dodds et al., 2015) in avoiding pitfalls (Silaghi-Dumitrescu, 2016, 2017) inherent to smaller-sample or excessively localized or excessively personalized (hence, potentially subjective) commentaries. Qualitative assessments of cross-cultural aspects, mostly based on individual and personal commentaries (e.g., (Blaga, 1965)) 
have more recently been at times reinforced and at times expanded by resorting to quantitative statistic data - e.g., based on sociological or psychological questionnaires administered to representative samples of populations(David, 2015; Silaghi-Dumitrescu, 2017), or by semantic analyses of large amounts of representative texts (Dodds et al., 2015). Simply looking at absolute values of numerical parameters for a country (e.g., in the World Values Survey) may be argued to be of little practical use as long as comparisons are not performed versus its neighbors, or versus culturally-related countries as well as versus culturally-unrelated ones. By practical use, we imply here the possibility of discerning among the factors that control/dictate those numerical results - and more specifically discern among internal elements intrinsic/peculiar to that country versus external factors such as type of culture (with its varying interpretations such as type of language, type of religion, type of political system) or geographical location (whether in terms of clustering neighbors together or in terms of clustering countries with common types of geographies - e.g., island vs. mainland, diverse versus mono-terrain, mountainous vs. flatlands etc).

National anthems have been a topic for sociological and cultural analyses, including interpretations / commentaries on their nationalism, family, sexism, suicide rates and others - with cross-cultural implications in several cases (Abril, 2012; Barnes, Pomerantz, \& Yashko, 2016; Boufoy-Bastick, 2012; Gilboa \& Bodner, 2009; Guerrini \& Kennedy, 2009; Kelen, 2014, 2015; Kyridis et al., 2009; Lauenstein, Murer, Boos, \& Reicher, 2015; Lester \& Gunn, 2011; Liao, Zhang, \& Zhang, 2012; Oluga, Seng, \& Rajoo, 2016; Rodríguez, 2016; Siska, 2016; Sondermann, 2013; Vörös et al., 2016; Winstone \& Witherspoon, 2016). Most such studies were, however, focused on a distinct theme and/or on a culturallylimited number of anthems. Items such as gloominess, nationalism, gender-bias or others were pointed out and in some cases numerical correlations were proposed - using a small set of anthems. Practical implications were proposed - such as the need to change or replace national anthems with merrier / more positively-oriented versions so as to reduce the rate of suicide in the respective nation (Lester \& Gunn, 2011). However, due to the generally small number of anthems analyzed in each of these previous studies, and due to the narrow scope of each previously-proposed theme, it is so far unclear what part those previously-identified theme play in the economy of the national anthems. Are they present/applicable to the majority of anthems or only to a small subset? Are they the only ideological / sociological / ontological directions present in the anthems? If not, how many other such directions are out there? Systematic reviews - and, arguably necessarily, comparative ones across as many / diverse countries / cultures as possible may offer insight into how a nation views itself (and then in this way also indirectly into its ideological / sociological / ontological priorities). The text of the anthem would of course offer such a view into the state of things at the adoption of the anthem - though that fact that a country still stands by that anthem is also relevant; for instance, over the past 100 years Romania has changed 5 anthems - while other countries have changed none.

Presented here is an analysis of topics present in national anthems. By contrast to previous studies, no local or cultural limits are set in selecting which anthems are analyzed. The goal is to identify the pervasive topics in national anthems, and then to establish whether connections may be established between these topics and some basic societal features. Unlike previous studies, all currently-valid anthems (except those very recent or those of still-disputed territories) are analyzed, and no a priori limits are set in terms of identifying possible topics - neither in terms of number nor in terms of subject area. It will be shown that these topics can be grouped in more general themes, the occurrence of which can be linked, albeit weakly, to macro-indicators such as age of country, its wealth (as estimated by the gross domestic product (GDP) per capita), internal economical inequalities (as defined the Gini coefficient with respect to family incomes), size of armed forces, inequality-adjusted human development index (IHDI), and a number of parameters from the World Values Surveys (WVS). 


\section{Methodology}

Data concerning the anthems, including the English version of the text (with caveats discussed by (Oluga et al., 2016)), the length, the date of adoption as well as other data relating to the countries (GDP per capita cf. World Bank, the inequality Gini index/coefficient based on family income, population, armed forces, date of independence, wars fought since independence in current form, inequalityadjusted human development index, various parameters from the World Values Survey) were from Wikipedia.org (https://en.wikipedia.org/wiki/List_of_sover eign_states_by_date_of_formation,

https://en.wikipedia.org/wiki/List_of_countri es_and_territories_by_population_density, https://en.wikipedia.org/wiki/List_of_nation al_anthems,

https://en.wikipedia.org/wiki/Category:Lists _of_wars_by_country,

https://en.wikipedia.org/wiki/List_of_countri es_by_inequality-adjusted_HDI,

https://en.wikipedia.org/wiki/List_of_countri es_by_income_equality)

http://www.worldvaluessurvey.org and http://www.national-anthems.org/.

Anthems for 186 countries were analyzed initially for content, not including states that are currently in the process of international recognition and/or of establishing their independent structures (see appendices and Tables for complete list). Within each anthem, the meaning or implication of each verb, noun, adjective, pronoun or adverb were noted and placed in semantic categories as described in the Results section. The number of categories was not restricted; each time a word was found which would not fit in a previously-defined category, a new category was defined. A number of 37 categories emerged after analysis of all anthems. A logical value was attributed for each anthem with respect to each semantic category: 1 if the topic was found mentioned in the anthem, 0 if not. The number of repetitions of the same word or the same semantic category in an anthem was not counted.
An analysis of the possible clustering of the 37 categories was then performed. This analysis was performed by two types of methodologies. In a purely statistical ab initio methodology, all 37 logical values (for the 37 categories) for each anthem were summed up and their correlation with a number of country-related parameter (Gini, GDP/capita, age, size, military) was calculated. Then, for each of the five country-related parameters, a composite indicator was created mathematically by iterative removal of each of the 37 logical parameters pertaining to each of the 37 semantic categories, until a maximum value of the correlation coefficient was reached between the new composite indicator and the country-related parameter. An alternative analysis was performed on empirical basis by clustering together the semantic categories based on intuitive categories:

identity/positive/pride/fight/structure/ene my, definition (items that define the identity of the country/individual) / comfort (items that relate to the citizen's material or spiritual comfort) / aggression (items related to explicit/active conflict and fighting) / elation (items strictly related to praising one's country) / integration (items relating to the individual's integration in the group), material topics (items that one would physically be able to touch), action/changerelated items, and spiritual/intellectualrelated items (items that are not concrete and do not reflect an action), resource-related / self-assertion-related / and antagonismrelated, or entropy (an indication of the internal order/structure of the society and of its complexity), inertia (an indication of the interest in / resistance towards change), and assimilatory-expansion (items describing a will to transcend current limits and limitations in relation to the outside world to win, conquer, convince, absorb). Then, the statistical $a b$ initio composite indicators were analysed by contrast with the empirical ones.

Correlations between the anthem data and general objective numerical parameters of the country (Gini coefficient, population, GDP and others) were performed only on a set of 145 countries for which such data were available. 
Additionally, for each anthem a number of numerical parameters were calculated/noted: number of verses, date of adoption, date when country became independent/sovereign, number of wars fought since independence in the current form (e.g., for Turkey only since its reorganization as republic starting 1919; for Russia only after reinstatement as independent state in 1991; for Switzerland and Spain only after the Napoleonic wars; for Germany only after 1871) and which wars were lost, won, or ended in unclear manner (stalemates, or cases of civil wars where both sides would claim to represent the country, or wars still ongoing).

For a smaller number of countries, for which such data were available (51), correlations were also examined with parameters extracted from the World Values Survey database, wave 6: 2010-2014 (http://www.worldvaluessurvey.org). For these countries, correlations with the inequality-adapted human development index (IHDI) were also analysed. Calculations were performed within a Microsoft Excel spreadsheet with standard formulae.

\section{Results and Discussion}

\section{Topics Identified}

The text of each anthem was analyzed for occurrences of topics, as described in Materials and Methods. Those identified are listed here alphabetically:

- Ancestors/past and synonyms: any mention of forefathers, general or explicit (e.g., of past national heroes, previous leaders etc.), or of the history of the country (whether in positive or negative sense)

- Beauty and its synonyms - where explicitly mentioned. Not counted here were the instances where the anthem would reference/describe "green mountains"/"golden fields" /"rich soils"/etc

- Build, building, work, construction and synonyms describing actions where one deposits effort towards actions other than fight/war - generally with positive connotations
- Country name, where mentioned explicitly

- Courage, valour and synonyms - generally in conflict-related references

- Democracy and its tools, beyond simple mention of equality or freedom

- Enemies and synonyms thereof mentioned explicitly by name or generally, with a conflictual connotation

- Ethnicity - where mentioned explicitly

- Family, family members (mother, father, sons, daughters etc.)

- In relation to family but not only to family, a separate section was noted for men and male characters

- Likewise, for women and female characters

- Fight, fighting, war and synonyms

- Flag, national flag, national colors (where explicitly mentioned)

- Forever/never/eternity and similar references to absolute time-related statements

- Future and general references thereof, including sentences that describe future actions without explicitly mentioning the word "future". This also includes absolute temporal references such as "forever free", even if overlapping with item 14.

- Geography, in most general senses including reference to the country's position geographically ("by the sea", "island", "southern" etc.) or to its geographical composition (mountains, woods, river etc. - whether mentioned in general sense or explicitly by name)

- Glory and synonyms thereof

- Independence, freedom and synonyms thereof

- Joy, happiness and synonyms thereof

- Land, soil, motherland, fatherland and synonyms

- Law, rules and structures of law, the action of ruling (not counting here the explicit mentioning of leaders, rulers or religion)

- Leaders/rulers - limited to the ones currently in office, whether mentioned by name or by official title

- Love and synonyms

- Loyalty, pledges of loyalty and related explicit stances (not including implicit or indirect statements such as "I will die for my country")

- Peace and synonyms thereof 
- Poverty and wealth - generally any issue related to the personal financial/material state

- Pride and related terms

- Religion, whether mentioned explicitly or indirectly via its major tenets (e.g. "God save the..."), but not including terms such as "sacred" which may carry non-religious meanings as well and are accounted for separately

- Revolution, insurrection and related terms

- Sacred (see also religion, above)

- Sacrifice for a/the cause

- Salvation, where mentioned explicitly as such

- Sorrow, sufferings and related terms

- Treason, traitors and related terms

- Tyrants, slavery, chains, shackles and related terms

- Unity, unification and related terms

- Win, winning, victory and related terms in conflict-related contexts

For each of the above-mentioned topics, occurrence was marked in binary manner (present/not present in the respective anthem). Table 1 summarizes the degree of popularity of each topic in the 186 anthems analyzed initially. A complete list of the data, detailed by country and topic, is listed in the Appendices.

As seen from Table 1, some $30 \%$ of the anthems appear to contain no explicit reference to the country or to its name. Likewise, some $30 \%$ of the anthems do not refer to any future action: they simply describe a current and/or past state of things. Independence, pride and loyalty are found in some $60 \%$ of the anthems. Approximately half of the anthems refer to unity, geography, ancestors, religion, family, love, or contain a reference to eternity. Towards one-third of the anthems refer to poverty or wealth, glory, sacredness, courage, joy, law, peace, work, fight, sacrifice, male characters, beauty, ethnicity, or national colours. One-fifth or less of the anthems will refer to victory, enemy, female characters (notably, approximately half as often as male characters), tyrants, leaders. Less than one tenth of the anthems will mention salvation, democracy, treason, or revolution.

Table 1. Topics in national anthems.

Percentages of anthems that refer to each topic are given

\begin{tabular}{|c|c|c|c|c|c|}
\hline Theme & $\mathbf{\%}$ & Theme & $\mathbf{\%}$ & Theme & $\mathbf{\%}$ \\
\hline land & $72 \%$ & poverty/wealth & $41 \%$ & flag/colors & $26 \%$ \\
\hline future & $70 \%$ & glory & $39 \%$ & sorrow & $25 \%$ \\
\hline country name & $68 \%$ & sacred & $37 \%$ & win & $20 \%$ \\
\hline independence/freedom & $63 \%$ & courage & $35 \%$ & enemy & $18 \%$ \\
\hline pride & $63 \%$ & joy/happy & $35 \%$ & woman & $17 \%$ \\
\hline loyalty & $60 \%$ & law & $35 \%$ & tyrant & $17 \%$ \\
\hline geography & $52 \%$ & peace & $35 \%$ & leader & $17 \%$ \\
\hline religion & $52 \%$ & build/work & $34 \%$ & salvation & $9 \%$ \\
\hline unity & $49 \%$ & fight & $34 \%$ & treason & $6 \%$ \\
\hline forever/never & $46 \%$ & sacrifice & $34 \%$ & democracy & $3 \%$ \\
\hline ancestors/past & $45 \%$ & man & $32 \%$ & revolution & $3 \%$ \\
\hline family & $44 \%$ & beauty & $31 \%$ & & \\
\hline love & $42 \%$ & ethnicity & $27 \%$ & & \\
\hline
\end{tabular}

The topics listed in Table 1 may be intuitively clustered in sets related by general semantic themes. Table 2 shows a range of such possible groupings, and Supporting
Information lists individual scores for each country along these proposed coordinates. Separately from Table 2, an alternative manner of grouping the 37 items is proposed based on their statistical correlation with 
numerical empirical parameters related to each county. Thus, a few sets of publicly available general material data on the respective countries (145 of the total 186, excluding countries where the data would not be available or where the very recent independence or very recent wars/statehood changes would not allow meaningful comparisons - e.g., Lybia, Syria, Kosovo, Sudan, South Sudan) were thus employed: area size, population size, date of independence, GDP (gross domestic product), Gini coefficient (a measure of inequality), size of armed forces. These were selected since they may be expected to hold relevance to various of the coordinates defined in Table 2 (whether it be for material resources - GDP, structure of the society - Gini, interest in fight - armed forces, need for assertion - size, age, etc.). A number of 5 coordinates were thus identified as follows (the reader is referred to Supporting Information for a detailed Table containing such correlations between empirical/material country data and anthemderived coordinates):

- Coordinate v1 unites the Table 1 terms build, country name, ethnicity, woman, independence, land, love, peace, pride, revolution, treason, unity. This choice was the one that allowed the best possible correlation with the age of the country ( $\mathrm{r}=-$ 0.3 ) - although in fact v1 also correlates even slightly better with GDP/capita and with military parameters as well as - of the other composite anthem-derived coordinates, with identity, pride, definition (highest correlation, $\mathrm{r}=0.7$ ), comfort, elation, integration, and a few other related ones.

- Coordinate v2 contains the themes build, flag, love, peace, religion, sacrifice. V2 was defined for best correlation with Gini $(\mathrm{r}=0.5)$, though it also displays weak correlations with GDP/capita and with military parameters, as well as with a few other composite parameters - especially pride $(\mathrm{r} \sim 1)$.

- Coordinate v3 contains the themes build, courage, flag, law, peace, revolution, sacred, sacrifice, unity. V3 was defined for best correlation with GDP/capita $(-r=0.5)$; it also displays correlations with Gini and with military parameters, as well as with a few other composite parameters (of which the most notable is fight, $\mathrm{r}=1$ ).

- Coordinate v4 contains the themes build, country name, family, woman, love, peace, tyrant. V4 was defined for best correlation with military items ( $\mathrm{r}=0.4$ for active military/capita); it also displays weak correlations with Gini and GDP/capita, as well as with several composite anthemderived indicators (highest for structure, $\mathrm{r} \sim 1$ ).

- Coordinate v5 consists of the sum of ancestors, build, country name, courage, democracy, enemy, ethnicity, fight, flag, geography, glory, peace, revolution, pride, tyrant). V5 was defined for best correlation with population density $(\mathrm{r}=0.3)$; it also display weak correlation with GDP/capita and with various composite parameters (highest with enemy, $\mathrm{r}=1$ ).

Overall, the mathematically-derived v1-v5 coordinates are largely similar to some of the intuitively-derived ones of Table 2: v1 overlaps mostly with definition/identity, v2 overlaps with pride, v3 with fight, v4 with structure and v5 with enemy. In that respect, close coincidence of the v1-v5 set with the first five-coordinate set in Table 2 may be noted - the main difference being that the positive coordinate of Table 2 tends to be dissipated between v1 and v2 (and hence may be judged to have been superfluous, at least in terms of its usefulness in relating to the macro-indicators analyzed in the present study - GDP, population etc.). 
Table 2. Possible aggregations of the 37 topics in national anthems into major themes.

\begin{tabular}{|c|c|c|}
\hline Theme & Includes & $\begin{array}{c}\text { Incidence in } \\
\text { anthems }\end{array}$ \\
\hline Identity & Ancestors, ethnicity, family, man, woman, geography, unity & $38 \%$ \\
\hline Positive & Beauty, build, future, joy, love, peace, wealth & $41 \%$ \\
\hline Pride & $\begin{array}{l}\text { Country name, flag, forever, independence, land, loyalty, } \\
\text { pride, sacred }\end{array}$ & $62 \%$ \\
\hline Fight & Courage, fight, glory, sacrifice & $20 \%$ \\
\hline $\begin{array}{l}\text { Structure of the } \\
\text { society }\end{array}$ & Democracy, law, leader, religion & $15 \%$ \\
\hline Enemy & $\begin{array}{c}\text { Enemy, revolution, salvation, sorrow, treason, tyrant, } \\
\text { victory }\end{array}$ & $14 \%$ \\
\hline Definition & $\begin{array}{l}\text { ancestry, ethnicity, unity, flag, family, religion, land, } \\
\text { geography, country name, man, woman, independence }\end{array}$ & $46 \%$ \\
\hline Comfort & Pride, wealth, peace, love, joy, future, beauty, work & $44 \%$ \\
\hline Aggression & $\begin{array}{l}\text { win, tyrant, treason, sorrow, salvation, sacrifice, revolution, } \\
\text { fight, enemy, courage }\end{array}$ & $23 \%$ \\
\hline Elation & sacred, pride, glory, forever & $46 \%$ \\
\hline Integration & unity, loyalty, leader, law, democracy & $31 \%$ \\
\hline Material topics & $\begin{array}{l}\text { Ancestors, build/building, family, man, woman, geography, } \\
\text { land, leader, poverty/wealth, tyrant }\end{array}$ & $38 \%$ \\
\hline Action-related items & Fight, revolution, sacrifice, salvation, treason, win & $20 \%$ \\
\hline $\begin{array}{l}\text { Spiritual/intellectual } \\
\text { items }\end{array}$ & $\begin{array}{l}\text { Beauty, country name, courage, democracy, ethnicity, flag, } \\
\text { forever, future, glory, independence, joy, law, love, loyalty, } \\
\text { peace, pride, religion, }\end{array}$ & $48 \%$ \\
\hline Resources & Poverty/wealth, land, geography, build & $50 \%$ \\
\hline Self-assertion & $\begin{array}{l}\text { Unity, sorrow, sacred, religion, pride, loyalty, leader, law, } \\
\text { joy, independence, glory, future, forever, flag, woman, man, } \\
\text { family, ethnicity, democracy, courage, country name, } \\
\text { beauty, ancestors, }\end{array}$ & $41 \%$ \\
\hline Antagonism & $\begin{array}{c}\text { Win, tyrant, treason, salvation, sacrifice, revolution, peace, } \\
\text { fight }\end{array}$ & $22 \%$ \\
\hline Entropy & $\begin{array}{l}\text { Build, democracy, ethnicity, family, man, woman, law, } \\
\text { leader, religion, treason, tyrant, unity }\end{array}$ & $27 \%$ \\
\hline Inertia & $\begin{array}{l}\text { Sorrow, sacred, pride, peace, love, joy, land, geography, flag, } \\
\text { forever, ethnicity, family, country name, ancestor }\end{array}$ & $47 \%$ \\
\hline $\begin{array}{l}\text { Assimilatory } \\
\text { expansion }\end{array}$ & $\begin{array}{l}\text { Win, salvation, sacrifice, revolution, poverty/wealth, } \\
\text { loyalty, independence, glory, future, fight, courage, enemy }\end{array}$ & $38 \%$ \\
\hline
\end{tabular}

\section{Correlations with World Values Survey (VWS) data and with IHDI}

For a smaller number of countries (51) data from the series of Wold Values Survey are also available on 200+ topics/items - of which several were selected for comparison with the anthem related data; inequalityadjusted human development index data
(IHDI) were also included. Correlation coefficients were calculated between the sets of data - and in selected cases (where larger than 0.4) they are discussed. To illustrate the degree of significance of these correlations, one may exemplify that for a negative -0.7 correlation coefficient between IHDI and number of religious people, that the top ten countries in terms of IHDI within the present set are found to rank on average 43 (in the 
set of 51 countries) based on the degree to which they consider religion important or very important. At the lower limit, the significance of a -0.4 correlation coefficient between the age of the country and the importance of religion (cf. WVS), may be illustrated by the fact that the top 10 countries where religion is important or very important are at the same time ranked on average 31 in terms of age; by contrast, the bottom 10 ones in terms of religion are indeed ranked distinctly higher in terms of age, at an average of 18 -- i.e. the importanceof-religion rank goes oppositely with respect to the age rank. Thus, these correlation coefficients indicate general trends but not universally-applicable exact laws -and nor should they be expected to do more, considering the diversity of external factors involved, the number of variable parameters and the relatively small size of the samples.

The age of the anthem shows a negative correlation coefficient of $-0,4$ with the proportion of citizens stating that religion is very important or rather important. Newer anthems thus apparently show a small tendency to be found in countries with less religious people. This is not unexpected: indeed, government secularity is a feature more often seen in modern states/societies; than it was in medieval/feudal/premodern societies.

There is also a 0.4 correlation coefficient between the number of people stating that religion is fairly important and the composite indexes identity and definition. Thus, in countries that have a tendency to insist on more explicitly defining their national identity in the anthems, religion appears to be more important. There are also correlations between the number of people stating that religion is very important or rather important and those stating that work is "very important" $(0,8)$, or those stating that they are "rather happy (0.5), or those who "agree" or "agree strongly" that men are better leaders than women" $(0,6)$, those willing to fight for their country (0.5), those stating that "greater respect for authority" would be a good thing to have in the future, those for whom "competition is good" (0.7), those who are "proud" or "very proud" of their nationality
(0.7), and those who state that they are worried about a war "very much" or "a great deal", and inverse correlations with those stating that leisure in "very important" or "rather important" (-0.5), or those for whom "most people can be trusted (-0.7). Last but not least, this religious parameter also inversely correlates with the inequalityadjusted human development index (IHDI, 0.7). The above considerations make for a picture where newer states/countries (hence, less developed, more anchored in pre-modern traditions) have anthems that place a greater emphasis on explicitly defining/listing their identity.

Along the same lines, one may note that the number of people stating that family is "very important" or rather important correlates with the composite index elation (0.4), and inversely correlates with the number of wars and with the number of wars won $(-0.6$, each).

The number of people for whom "work is very important" correlates with the number of topics present in the anthems (0.4) but not with the length of the anthem, and inversely with the area of the country $(-0.4)$. The number of people for whom work is "very important" or "rather important" also directly correlates with the Gini index, hence with the degree of inequality in the society (0.4) and with the composite parameters of the anthems, v2 and v5 (those similar to pride and enemy, 0.4 , each).

The number of people who "agree" that "being a housewife is just as fulfilling as working for pay" correlates inversely with the anthem-derived composite indexes entropy, material and definition (-0.4, each) and with the number of people who are "very proud" or "proud" of their nationality, as well as directly with IHDI . The number of people who "agree strongly" with the same statement also correlates directly with the composite index elation (0.4), with the number of people who state that family is "very important" $(0.4)$, the number of people who "agree" or "agree strongly" that men are better leaders than women (0.6), the number of people who agree that "having a strong leader who does not have to bother with parliament and elections" 
is "very good" (0.4), and inversely with the number of wars, the number of wars won, the percentage of wars won, the ratio of wars won/lost, the number of people who state that work of leisure are "very important" (0.4 , each). The number of people who "agree" or "agree strongly" that men are better leaders than women correlates with the date of adoption of the anthem $(0,4)$, the number of people who would not want immigrants or people of other races as neighbours $(0.5$ and 0.6 , respectively), the number of people willing to fight for their country $(0,5)$, the number of people who want more government ownership of businesses (0.5), the number of people who think that competition is "good" (0.5), the number of people who want a strong leader at the expense democratic institutions (0.4), as well as with the composite indexes spirit and selfassertion (0.4), and inversely with the number of wars $(-0.4)$ and of wars won $(-0.5)$, the number of people who state that leisure is "very important" or "rather important" (-0.6), IHDI $(-0.6)$, the number of people who are "very proud" or "quite proud" of their nationality", and the number of people who worry about a war "very much" or "a great deal". Overall this is consistent with a picture where newer, less-developed countries are better anchored in a patriarchal setting and more insecure regarding their chances for the future. When considering patriarchy, one may also add that of the 51 nations for which the WVS correlations are available, only 4 have in their anthems some reference to feminine characters - as opposed to 15 for the male characters; from this point of view, one may consider that anthems in general tend to be gender-biased in a patriarchal sense.

The number of people who state that "most people can be trusted" correlates with the number of topics present in the anthem ($0.4)$, with the anthem-derived composite indexes elation, spirit and v3 (-0.4), as well as with the Gini index (-0.4), number of wars and number of wars won $(0.4$, each), the number of people wishing for greater respect for authority $(-0.4)$, the number of people wanting more private ownership of businesses (-0.4), the number of people stating that competition is "good" (-0.4), IHDI $(0.4)$, the number of people who are "very proud" of their nationality $(-0.5)$, and the number of people who worry about a war "very much" or "a great deal" (-0.6).

The number of people who would not want immigrants or people of other races as neighbours correlates with the length of the anthem $(-0.4 /-0.5)$, size of armed forces per capita $(0.3 / 0.4)$, number of wars lost $(0.2 / 0.4)$, number of people who agree that men are better leaders than women (0.6), number of people who want more government ownership of businesses $(0.4 / 0.3)$, number of people for whom it would be "very good" to have a stronger leader at the expense of democratic institutions (0.4/0.3), and number of people who worry about a war "very much" or "a great deal" $(0.3 / 0.4)$.

The number of people willing to "fight for their country" correlates directly with the date of adoption of the anthem (0.5) and less so with the rest of the anthem-derived parameters. It also correlates with the number of wars and of wars won $(-0.4$, each), number of people who want more government ownership of businesses (0.4), the number of people stating that competition is "good" $(0.5)$, and the number of people who are "very proud" or "quite proud" of their nationality (0.5).

For the number of people stating that "greater respect for authority" would be a good thing to have in the future, correlations are seen with the anthem composite indexes pride, self-assertion, v3 and v4 (0.4, each), as well as with the Gini index (0.4), total size of armed forces (-0.4), the number of people stating that competition is "good" (0.5), IHDI $(-0.5)$, the number of people who are "very proud" or "quite proud" of their nationality $(0.5)$, and the number of people who worry about a war "very much" (0.4).

The number of people who agree that "having a strong leader who does not have to bother with parliament and elections" is "very good" or "fairly good" correlates with the anthem-derived composite index elation (0.4). Interestingly, it also correlates with the number of people for whom having a democratic political system is "fairly good" as one may expect since nations that are in 
the course of building democracy are facing a dilemma - between appreciating the fruits of democracy in richer / more developed nations on one hand, and a lack of patience in waiting for similar results from one's own newer democratic institutions on the other hand.

The inequality-adjusted human development index (IHDI) shows correlations with the number of topics present in the anthem (-0.4), with composite indexes definition, spirit, v1, v2, v4 (-0.4, each), as well as with the number of people who are "very proud" or "quite proud" of their nationality ($0.5)$, the number of people who trust other nationalities completely (0.5), and number of people who worry about a war "very much" or "a great deal" (-0.6).

The number of people who are "very proud" or "quite proud" of their nationality correlates with the date of adoption of the anthem (0.5), but less so with other parameters of the anthems. There is on the other hand a negative correlation with the number of wars and of wars won $(-0.5$, each).

The number of people who worry about a war "very much" or "a great deal" correlates with the sum of topics present in the anthem (0.4),with the composite index v2 (similar to pride in Table 2, 0.4), and also with the number of wars won $(-0.4)$.

The above discussions paint a picture where older, richer and more developed countries describe themselves as happier and more secure psychologically, have won more wars and are less concerned by impending conflicts (and vice-versa for the newer, less rich and less developed countries). To some extent this is reflected in the respective national anthems, in terms of their length, number of topics, and nature of topics (e.g., aggression, enemy, spirit, definition, elation, pride, self-assertion.

\section{Composite Indicators across Countries}

For a practical illustration of the above analyses, and perhaps offering a premise for confrontation with generally-accepted considerations about the respective countries drawn from more traditional and extensivelydocumented data sources, Table 3 gives a list where each country is labelled according to its featuring an extreme score along any of the coordinates described above (Table 2 and the v1-v5 set). Specifically, the thresholds for defining the Table 3 labels are defined by the lowest/highest $25 \%$ score below/above the median of the values registered along the respective axes for the 146 countries analysed). In examining Table 3 , one may take note of the exact meaning of each indicator in (e.g., "low enemy" implies that the respective anthems is distinctly less interested in enemyrelated topics, when compared to other anthems), but also of the number of indicators for each country.

The average number of topics highlighted in Table 3 (i.e., at higher-than-average rates compared to other countries) is 3.3 ; also, the median value has a similar value, 3 . A few countries have no marking at all in Table 3 suggesting that their anthems stand out in no way with respect to the world-average trends in anthems. These countries are Central African Republic, Chad, Chile, Gabon, Liberia, Norway, Uzbekistan, Zambia, Zimbabwe. They are closely followed by several others where only one outlying topic is found: Algeria, Belarus, Canada, Colombia, Republic of Congo, Ecuador, El Salvador, Estonia, Haiti, Iran, Laos, Luxembourg, Mali, Mexico, Mongolia, Nepal, Philippines, Portugal, Slovenia, Sri Lanka, Switzerland, Thailand. These two groups of countries thus appear to have the most "average" anthems. It must be reiterated that "average" refers to the statistics present in Tables 1 and 2, i.e., not that certain topics are not more pervasive than others - but rather that for this class of countries the typical focus is observed (e.g., prevalence of the topics land, future, country name, independence/freedom, pride, loyalty, or very low occurrence of topics such as salvation, treason, democracy, revolution).

Other countries, by contrast, have a very high number of markings in Table 3. This may be interpreted as a manifestation of, or aspiration towards, a higher-than-average individuality. While anthems in general do focus on defining the country's individuality as seen in Table 1, we are now discussing 
countries that go beyond this trend, noting that Table 3 highlights both cases where the incidence of a category of terms is low, or where it is high - i.e., overall, where the country happens to be different from the average. At the extreme in this respect are, with a number of outliers more than double compared to the world average (i.e., number of outliers ranging from 11 to 7: Burkina Faso, Czechia, Guatemala, Australia, Japan, Cape Verde, Slovakia, Djibouti, Bulgaria, Cambodia, Finland, France, Israel.

On the other hand, countries further fall into different categories when counting the types of outliers: high vs. low. The average of the "high" minus "low" count per country in Table 3 is -2 (and the median value is also similar). On one extreme there are Burkina Faso and Guatemala, with "high" outliers clearly exceeding the "low" ones - by 10 and 8 . These two countries are followed by Dominican Republic, Togo, Tunisia, Rwanda, Brazil, Cameroon, Romania, Bolivia, Malawi Paraguay, with "high" minus "low" counts ranging from 5 to 2 (vs. the average/median of -2 across the world). These would be the countries whose anthems most tend to stand out by highlighting certain sets of topics.

At the other extreme are the countries that highlight their differences from the world-average trends in anthems by avoiding/downplaying several of the possible topics. In this order, ranging from "high" minus "low" counts of -6 to -10 , these countries are: Cape Verde, Bosnia\&Herzegovina, Egypt, Germany, Latvia, Morocco, Papua New Guinea, South Africa, Tajikistan, Bulgaria, Finland, France, Israel, Djibouti, Slovakia, Australia, Japan, and Czechia. Thus, while some countries assert their higher-than-average effort towards individuality by more complex / richer terminology (Burkina Faso, Guatemala), others assert their individual style by suppressing most terms in favour of a few (Japan, Czechia).

To illustrate the above considerations, one may consider the text of the Czech anthem, for which Table 3 lists "low" for antagonism, self-assertion, spirit, action, integration, elation, aggression, enemy, structure, fight (which leads to the most negative "high" minus "low" score among all contries):

Where is my home, where is my home?

Water roars across the meadows,

Pinewoods rustle among crags,

The garden is glorious with spring blossom,

Paradise on earth it is to see.

And this is that beautiful land,

The Czech land, my home,

The Czech land, my home.

Indeed, there are no mentions of enemies (hence also no antagonism, no aggression), of any action, of spiritual items (in the sense of religion), no explicit mention of elation (joy, happiness), or of the structure of the society (cf. Table 2, this would have included mention of the topics democracy, law, leader, religion). The few topics that are mentioned in this anthem are focused around geographical description and mentions of country name and beauty - but not to an extent that would greatly exceed the average values; the highlight on these latter topics is rather given by the absence of the others.

Somewhere in the same range as Czechia, the French anthem also has a relatively large number of "low" items: resources, spirit, integration, comfort, structure, pride, positive:

Arise, children of the Fath
The day of glory has arriv
Against us of the tyranny
The bloody banner is raised
Do you hear, in the countrysi
The roar of those ferocious
They're coming right into
To slit the throats your
companions!
To arms, citizens,
Form your battalions,
Let's march, let's march!
That a tainted blood
Water our furrows!

Indeed, the French anthem has no (or little) explicit mentions of the respective terms as defined in Table 2. Thus, in terms of resources (defined in Table 2 as the sum of topics poverty/wealth, land, geography, build), the 
French anthem indeed makes no explicit mention to poverty or wealth, to the land, to its geography (e.g., mountains, location, fields etc), or to concepts related to building/creating anything. In terms of spiritrelated items (defined in Table 2 as the sum of topics beauty, country name, courage, democracy, ethnicity, flag, forever, future, glory, independence, joy, law, love, loyalty, peace, pride, religion) the French anthem indeed makes no reference to joy, religion, law, ethnicity, flag, future, pride, country name - though glory does remain mentioned. In terms of integration, theer is indeed no explicit mention in the French anthem for the items defined in Table 2 as part of this coordinate: unity, loyalty, leader, law, democracy; the latter is perhaps ironic since the anthem dates back to the French Revolution, which common clichés often cite as being at the foundation of modern democracy). There is also nothing suggestive of comfort, pride, or positive in the French anthem - ultimately nothing but a call to arms against enemies that "slit throats" and towards "watering furrows with tainted blood". There is likewise no mention of the structure of the society (cf. Table 2 this would imply democracy, law, leader, religion)- and indeed this is the time when France was challenging the fabric of its state.

At the other end of the "high" minus "low" scale, one may look at the anthem of Burkina Faso, which stands out with particularly high scores on antagonism, self-assertion, spirit, action, integration, elation, aggression, comfort, enemy, fight - and the text is indeed at the antipodes of the Czech one, with repeated reference to suffering, enemies, fight, revolution, but also building, emancipation and others:

Against the humiliating bondage of a thousand years

Rapacity came from afar to subjugate them for a hundred years.

Against the cynical malice in the shape of neo-colonialism and its petty local servants.

Many gave in and certain others resisted. But the frustrations, the successes, the sweat, the blood
Have fortified our courageous people and fertilized its heroic struggle.

And one single night has drawn together The history of an entire people,

And one single night has launched its triumphal march.

Towards the horizon of good fortune.

One single night has brought together our people

With all the peoples of the World, In the acquisition of liberty and progress.

Motherland or death, we shall conquer.

Nourished in the lively source of the Revolution,

The volunteers for liberty and peace

With their nocturnal and beneficial energies of the 4th of August

Had not only hand arms, but also and above all

The flame in their hearts lawfully to free

Faso forever from the fetters of those who

Here and there were polluting the sacred soul of independence and sovereignty.

And seated henceforth in rediscovered dignity,

Love and honour partnered with humanity,

The people of Burkina sing a victory hymn To the glory of the work of liberation and emancipation.

Down with exploitation of man by man!

Forward for the good of every man

By all men of today and tomorrow, by every man here and always!

Popular revolution our nourishing sap.

Undying motherhood of progress in the face of man.

Eternal hearth of agreed democracy,

Where at last national identity has the right of freedom.

Where injustice has lost its place forever, And where from the hands of builders of a glorious world

Everywhere the harvests of patriotic vows ripen and suns of boundless joy shine.

Also towards the positive end of the "high" minus "low" score is Romania, with high scores on elation, aggression and fight, and a low score on positive: 
Wake up, Romanian, from your deadly sleep

Into which you've been sunk by the barbaric tyrants

Now, or never, your fate renew,

To which your enemies will bow.

Now or never let's give proof to the world

That in these veins still flows a Roman blood,

That in our chests we still maintain our pride in a name

The victor in his battles, the name of Trajan!

Watch on, shadows of highnesses, Mihai, Stefan, Corvinus,

The Romanian Nation, your great grandchildren,

With weapons in their arms, with your fire in their veins,

"Life in freedom or death!" shout all.

Priests, lead with your crucifixes! Because our army is Christian,

The motto is Liberty and its goal is holy,

Better to die in battle, in full glory,

Than to once again be slaves upon our ancient ground!

Indeed, the Romanian anthem mimics the French one in being essentially just a call to arms - but does so with more explicit references to items such as identity, structure or resources (several mentions of nationality, religion, ancestors, land etc.) - with only the non-positive attitude remaining similar to the French case. Instead, on the other hand, there is in the Romanian anthem more direct reference to the enemy and to the battle itself as well as to the "glory" of winning - hence the high scores on elation, fight and aggression.

Another illustrative example is the United Kingdom anthem, which stands out with a particularly high score on structure and a low score on identity:

God save our gracious Queen,

Long live our noble Queen,

God save the Queen:

Send her victorious,

Happy and glorious,

Long to reign over us:

God save the Queen.
O Lord, our God, arise,

Scatter her enemies,

And make them fall.

Confound their politics,

Frustrate their knavish tricks,

On Thee our hopes we fix,

God save us all.

Thy choicest gifts in store,

On her be pleased to pour;

Long may she reign:

May she defend our laws,

And ever give us cause

To sing with heart and voice

God save the Queen.

There is indeed in this anthem reference to structure, i.e., cf. Table 2, any of the topics democracy, law, leader, religion (hence the anthem refers to Lord, God, Queen, reign, laws). At the other end, in terms of identity (cf. Table 2 this would include references to ancestors, ethnicity, family, man, woman, geography, unity), the UK anthem may well refer to any country in the world: it has no explicit reference to the ethnicity, geographical details, ancestors - nor even to the concept of family or the explicit mention of men or women as individual persons.

The USA anthem also offers a relevant analysis in parallel to the French and the UK anthems:

O! say can you see,

By the dawn's early light,

What so proudly we hailed,

At the twilight's last gleaming,

Whose broad stripes and bright stars,

Through the perilous fight,

O'er the ramparts we watched,

Were so gallantly streaming?

And the rockets' red glare,

The bombs bursting in air,

Gave proof through the night,

That our flag was still there;

o! say does that star-spangled

banner yet wave,

$O$ 'er the land of the free,

And the home of the brave?

As in the case of the UK anthem, there is essentially no indication of the identity of the country/society (hence, the "low identity" 
label in Table 3). Also, while the verses describe a battle setting, there is no mention whatsoever of the enemy (hence "low enemy" in Table 3). Much like its historically-twinned French anthem (i.e., both originating from revolutions and at similar times), there is also no mention of items related to the structure of the society.

Table 3. Notable features derived from the analysis of the anthems and country data in the present work.

\begin{tabular}{|c|c|}
\hline Anthem of & Description \\
\hline Albania & -low resources-high action-low material- \\
\hline Algeria & -low structure- \\
\hline Angola & -high antagonism-low structure-high fight- \\
\hline Argentina & -high elation-low structure- \\
\hline Armenia & -low integration-low structure- \\
\hline Australia & $\begin{array}{l}\text {-low antagonism-low resources-low action-low integration-low elation-low } \\
\text { aggression-low enemy-low structure-low fight- }\end{array}$ \\
\hline Austria & -high resources-low enemy-low structure- \\
\hline Azerbaidjan & -low structure-high fight- \\
\hline Bangladesh & -low antagonism-low action-low integration-low structure-low fight- \\
\hline Belarus & -low structure- \\
\hline Belgium & -high integration-low fight- \\
\hline Belize & -high resources-high material-low elation- \\
\hline Benin & -high resources-low structure- \\
\hline Bhutan & -low action-low aggression-low definition-low enemy-low fight- \\
\hline Bolivia & -high self-assertion-high fight- \\
\hline $\begin{array}{l}\text { Bosnia\&Herz } \\
\text { egovina }\end{array}$ & -low antagonism-low action-low aggression-low enemy-low structure-low fight- \\
\hline Botswana & -low action-low aggression-low enemy-low fight- \\
\hline Brazil & -high resources-high comfort-low enemy-high positive- \\
\hline Bulgaria & $\begin{array}{l}\text {-low antagonism-low action-low integration-low aggression-low enemy-low } \\
\text { structure-low fight- }\end{array}$ \\
\hline Burkina Faso & $\begin{array}{l}\text {-high antagonism-high self-assertion-high spirit-high action-high integration-high } \\
\text { elation-high aggression-high comfort-high enemy-high fight- }\end{array}$ \\
\hline Burundi & -high self-assertion- \\
\hline Cambodia & $\begin{array}{l}\text {-low antagonism-low action-high integration-high elation-low aggression-low } \\
\text { enemy-high structure- }\end{array}$ \\
\hline Cameroon & -high resources-high elation-high comfort-low structure- \\
\hline Canada & -low enemy- \\
\hline Cape Verde & $\begin{array}{l}\text {-low antagonism-high resources-low action-low integration-low aggression-low } \\
\text { enemy-low structure-low fight- }\end{array}$ \\
\hline $\begin{array}{c}\text { Central } \\
\text { African } \\
\text { Republic }\end{array}$ & 0 \\
\hline Chad & - \\
\hline Chile & - \\
\hline China & -low elation-low structure- \\
\hline Colombia & -high fight- \\
\hline
\end{tabular}




\begin{tabular}{|c|c|}
\hline Anthem of & Description \\
\hline $\begin{array}{l}\text { Congo, Dem. } \\
\text { Republic }\end{array}$ & -low enemy-low structure- \\
\hline $\begin{array}{l}\text { Congo,Republ } \\
\text { ic }\end{array}$ & -low structure- \\
\hline Costa Rica & -high comfort-low structure- \\
\hline Cote d'Ivoire & -low action-low aggression-low enemy-low structure- \\
\hline Croatia & -low antagonism-low action-low enemy- \\
\hline Cyprus & -low resources-low integration-low enemy-low structure- \\
\hline $\begin{array}{c}\text { Czech } \\
\text { Republic }\end{array}$ & $\begin{array}{l}\text {-low antagonism-low self-assertion-low spirit-low action-low integration-low } \\
\text { elation-low aggression-low enemy-low structure-low fight- }\end{array}$ \\
\hline Denmark & -high material-low elation- \\
\hline Djibouti & $\begin{array}{l}\text {-low resources-low material-low integration-low definition-low enemy-low } \\
\text { structure-low identity- }\end{array}$ \\
\hline $\begin{array}{l}\text { Dominican } \\
\text { Republic }\end{array}$ & -high self-assertion-high action-high elation-high aggression-high fight- \\
\hline Ecuador & -low enemy- \\
\hline Egypt & -low antagonism-low action-low aggression-low enemy-low structure-low fight- \\
\hline El Salvador & -low structure- \\
\hline Estonia & -low enemy- \\
\hline Ethiopia & -low action-low enemy- \\
\hline Fiji & -low antagonism-low action-high elation-low aggression-low enemy- \\
\hline Finland & $\begin{array}{l}\text {-low antagonism-low action-low integration-low aggression-low enemy-low } \\
\text { structure-low fight- }\end{array}$ \\
\hline France & $\begin{array}{l}\text {-low resources-low spirit-low integration-low comfort-low structure-low pride-low } \\
\text { positive- }\end{array}$ \\
\hline Gabon & - \\
\hline Georgia & -low antagonism-low action-low integration-low aggression-low enemy- \\
\hline Germany & -low antagonism-low action-low elation-low aggression-low enemy-low fight- \\
\hline Ghana & -high resources-low action- \\
\hline Greece & -low resources-low integration-low enemy-low structure- \\
\hline Guatemala & $\begin{array}{l}\text {-high antagonism-high self-assertion-high resources-high material-high elation- } \\
\text { high aggression-high comfort-low structure-high fight-high pride- }\end{array}$ \\
\hline Guinea & -low enemy-low structure-low positive- \\
\hline $\begin{array}{l}\text { Guinea- } \\
\text { Bissau }\end{array}$ & -high antagonism-high resources-low structure- \\
\hline Guyana & -high resources-high definition-low enemy- \\
\hline Haiti & -low elation- \\
\hline Honduras & -low enemy-low structure- \\
\hline Hungary & -low integration-high aggression-high definition- \\
\hline Iceland & -high resources-low action-low integration-low fight- \\
\hline India & -low comfort-low fight-low positive- \\
\hline Indonesia & -low enemy-low structure- \\
\hline Iran & -low enemy- \\
\hline Ireland & -low elation-low comfort-low structure-low positive- \\
\hline Israel & $\begin{array}{l}\text {-low antagonism-low action-low elation-low aggression-low enemy-low structure- } \\
\text { low fight- }\end{array}$ \\
\hline Italy & -low resources-low positive- \\
\hline
\end{tabular}




\begin{tabular}{|c|c|}
\hline Anthem of & Description \\
\hline Jamaica & -low resources-high structure-low fight-low identity- \\
\hline Japan & $\begin{array}{l}\text {-low antagonism-low spirit-low action-low elation-low aggression-low definition- } \\
\text { low enemy-low fight-low pride- }\end{array}$ \\
\hline Jordan & -low resources-high elation- \\
\hline Kazakhstan & -low antagonism-low action-low enemy-low structure- \\
\hline Kenya & -low action-low aggression-low enemy- \\
\hline Kyrgyzstan & -high definition-low structure-low fight- \\
\hline Laos & -low fight- \\
\hline Latvia & -low antagonism-low action-low integration-low aggression-low enemy-low fight- \\
\hline Lesotho & -low action-low integration-low fight- \\
\hline Liberia & - \\
\hline Lithuania & -low antagonism-low action-low aggression-low enemy-low fight- \\
\hline Luxembourg & -low action- \\
\hline Macedonia & -low elation-low comfort-low enemy-low positive- \\
\hline Madagascar & -low action-low aggression-low enemy-low fight- \\
\hline Malawi & -high resources-high material- \\
\hline Malaysia & -low elation-low enemy-high structure- \\
\hline Mali & -high resources- \\
\hline Mauritania & -low resources-low material-low elation- \\
\hline Mauritius & -low action-low aggression-low enemy- \\
\hline Mexico & -low integration- \\
\hline Moldova & -low antagonism-low action-low integration-low structure- \\
\hline Mongolia & -high elation- \\
\hline Montenegro & -low action-low fight- \\
\hline Morocco & -low antagonism-low action-low elation-low aggression-low enemy-low fight- \\
\hline Mozambique & -high resources-low structure- \\
\hline Namibia & -low structure-high fight- \\
\hline Nepal & -low enemy- \\
\hline Netherlands & -low antagonism-low action-low comfort-low enemy-low positive- \\
\hline New Zealand & -low antagonism-low action-low integration-low fight-low identity- \\
\hline Nicaragua & -low integration-low enemy-low structure- \\
\hline Niger & -low enemy-low structure- \\
\hline Nigeria & -low action-high integration-low aggression-low enemy-high structure- \\
\hline Norway & - \\
\hline Pakistan & -low antagonism-low action-low enemy- \\
\hline Panama & -high comfort-low structure- \\
\hline $\begin{array}{l}\text { Papua New } \\
\text { Guinea }\end{array}$ & -low antagonism-low action-low integration-low aggression-low enemy-low fight- \\
\hline Paraguay & -high elation-high fight- \\
\hline Peru & -low action-low structure-low fight- \\
\hline Philippines & -low structure- \\
\hline Poland & -high action-low structure-low positive- \\
\hline Portugal & -low structure- \\
\hline Qatar & -low resources-low action- \\
\hline
\end{tabular}




\begin{tabular}{|c|c|}
\hline Anthem of & Description \\
\hline Romania & -high elation-high aggression-high fight-low positive- \\
\hline Russia & -low antagonism-low action-high elation-low aggression-low enemy- \\
\hline Rwanda & -high self-assertion-high spirit-high comfort- \\
\hline Senegal & -low structure-high identity- \\
\hline Serbia & -low fight-low positive- \\
\hline Seychelles & -low action-low aggression-low enemy-low fight- \\
\hline Sierra Leone & -high resources-low action-low aggression-low enemy-low fight- \\
\hline Slovakia & $\begin{array}{l}\text {-low antagonism-low action-low integration-low aggression-low enemy-low } \\
\text { structure-low fight-low positive- }\end{array}$ \\
\hline Slovenia & -low integration-low identity- \\
\hline South Africa & -low antagonism-low action-low elation-low aggression-low enemy-low fight- \\
\hline South Korea & -low antagonism-low action-low fight- \\
\hline Spain & -low action-low aggression-low enemy- \\
\hline Sri Lanka & -low fight- \\
\hline Suriname & -high integration-low enemy-high structure- \\
\hline Switzerland & -low fight- \\
\hline Tajikistan & -low antagonism-low action-low aggression-low enemy-low structure-low fight- \\
\hline Tanzania & -low action-low aggression-low enemy-high structure-low fight- \\
\hline Thailand & -low structure- \\
\hline The Gambia & -low action-low aggression-low enemy-low fight- \\
\hline Timor-Leste & -low integration-low structure-low identity- \\
\hline Togo & -high antagonism-high action-high aggression-high comfort-high fight- \\
\hline $\begin{array}{l}\text { Trinidad and } \\
\text { Tobago }\end{array}$ & -low antagonism-low action-low aggression-low enemy-low fight- \\
\hline Tunisia & $\begin{array}{l}\text {-high antagonism-high action-high aggression-high enemy-low structure-high } \\
\text { fight- }\end{array}$ \\
\hline Turkey & -low antagonism-low action-low identity- \\
\hline $\begin{array}{l}\text { Turkmenista } \\
\mathrm{n}\end{array}$ & -low structure-high pride- \\
\hline Uganda & -high resources-low action-low aggression-low enemy-low fight- \\
\hline Ukraine & -low integration-low structure- \\
\hline $\begin{array}{l}\text { United } \\
\text { Kingdom }\end{array}$ & -high structure-low identity- \\
\hline $\begin{array}{l}\text { United States } \\
\text { of America }\end{array}$ & -low integration-low enemy-low structure-low positive-low identity- \\
\hline Uruguay & -low structure-high fight- \\
\hline Uzbekistan & - \\
\hline Venezuela & -low action-low positive- \\
\hline Vietnam & -high action-low structure- \\
\hline Yemen & -low resources-low action-low integration-low fight- \\
\hline Zambia & - \\
\hline Zimbabwe & - \\
\hline
\end{tabular}




\section{Conclusion}

A simple analysis of topics present in national anthems is proposed, and possible correlations with country-related material data (size, military, income, World Values Survey parameters, inequality-adjusted human development index) are described. The number of topics, their bias, and/or the date of adoption correlate to more general societal features such as date of adoption, age of country, gross domestic product (GDP) per capita, Gini coefficient, size of armed forces, inequality, inequality-adjusted human development index, as well as a number of WVS parameters (related to religion, gender equality, attitude towards other nationalities/races, attitude towards work, attachment to democratic values etc).

\section{References}

Abril, C. R. (2012). A national anthem: Patriotic symbol or democratic action? In D. G. Hebert \& A. Kertz-Welzel (Eds.), Patriotism and nationalism in music education, 77-95 Farnham: Ashgate Publishing Ltd.

Barnes, C. D., Pomerantz, A., \& Yashko, L. (2016). Children Cover Your Eyes: Masculine Honor and the Role of Blind Patriotism in Teaching National Allegiance to Posterity. Political Psychology, 37(6), 817-834.

Blaga, L. (1965). Trilogia culturii. . Bucharest: Editura pentru Literatură Universală.

Boufoy-Bastick, B. (2012). Preserving national unity: Culturometric rapid appraisals of ethnic inequalities. New York: Nova Science Publishers, Inc.

David, D. (2015). Psihologia poporului roman. Bucharest: Editura Polirom.

Dodds, P. S., Clark, E. M., Desu, S., Frank, M. R.,
Reagan, A. J., Williams, J. R., ... Danforth, C. M. (2015). Human language reveals a universal positivity bias. Proc Natl Acad Sci $U S S$ A, 112(8), 2389-2394. https://doi.org/10.1073/pnas.14116781 12

Gilboa, A., \& Bodner, E. (2009). What are your thoughts when the national anthem is playing? An empirical exploration. Psychology of Music, 37(4), 459-484.

Guerrini, S. C., \& Kennedy, M. C. (2009). Crosscultural connections: An investigation of singing Canadian and American patriotic songs. Bulletin of the Council for Research in Music Education, 182, 31-39.

Kelen, C. K. (2014). Anthem Quality: National Songs and a Theoretical Survey. Bristol: Intellect Ltd.

Kelen, C. K. (2015). 'And ever give us cause': Understanding the investments of the 'Ur-anthem', 'God Save the King/Queen.' National Identities, 17(1), 45-61.

Kyridis, A. G., Mavrikou, A., Zagkos, C., Golia, P., Vamvakidou, I., \& Fotopoulos, N. (2009). Nationalism through stateconstructed symbols: The case of national anthems. International Journal of Interdisciplinary Social Sciences, 4(6), 113.

Lauenstein, O., Murer, J. S., Boos, M., \& Reicher, S. D. (2015). "Oh motherland I pledge to thee ...": A study into nationalism, gender and the representation of an imagined family within national anthems. Nations and Nationalism, 21(2), 309-329.

Lester, D., \& Gunn, J. F. Iii. (2011). Lyrics of national anthems and suicide rates. Psychological Reports, 109(1), 137-138.

Liao, T., Zhang, G., \& Zhang, L. (2012). Social Foundations of National Anthems: Theorizing for a Better Understanding of the Changing Fate of the National Anthem of China. Journal for the Theory of Social Behaviour, 42(1), 106-127.

Oluga, S. O., Seng, T., \& Rajoo, G. S. R. (2016). Replication, evocation and revocation of 
linguistic sexism in translated national anthems. 3L: Language, Linguistics, Literature, 22(2), 209-226.

Rodríguez, J. L. (2016). The National Anthem in Warao: Semiotic Ground and Performative Affordances of Indigenous Language Texts in Venezuela. Journal of Linguistic Anthropology, 26(3), 335-351.

Silaghi-Dumitrescu, R. (2016). Fatalism and Inaction Associations with the Romanian Ballad of the Little Ewe. Venets: The Belogradchik Journal for Local History, Cultural Heritage and Folk Studies, 7(3), 332-341.

Silaghi-Dumitrescu, R. (2017). Considerations on public perceptions within Romanian public discourse. Saarbrucken: Lambert Academic Publishing.

Siska, K. (2016). Fear Not! Turkish nationalism and the six arrows system -A state in search of a nation. Acta Juridica Hungarica, 57(3), 275-288.

Sondermann, K. (2013). Reading politically: National anthems as textual icons. In T. Carvell \& M. Hyvarinen (Eds.), Interpreting the Political: New Methodologies, 128-142. London: Taylor and Francis.

Vörös, V., Osváth, P., Vincze, O., Pusztay, K., Fekete, S., \& Ríhmer, Z. (2016). Word use and content analysis of the first verses of six national anthems: A transcultural aspect of suicidal behaviour. Psychiatria Danubina, 28(1), 82-85.

Winstone, N., \& Witherspoon, K. (2016). “It's all about our great Queen": The British National Anthem and national identity in 8-10-year-old children. Psychology of Music, 44(2), 263-277. 